\title{
Kontaktudvalget for det Tyske Mindretal - oprettelsen og de første år 1965-1973
}

\author{
Af Hans Schultz Hansen
}

Siden 1920 har det været en målsætning for de slesvigske mindretal at opnå indflydelse ad parlamentarisk vej. Fra begyndelsen opstillede Slesvigsk Parti og SSW henholdsvis nord og syd for grænsen kandidater ved valgene til folketing, rigsdag, forbundsdag og landdag. Det var ikke altid, at stemmerne rakte til et mandat. I tiden med nationalpolitisk konflikt betød det manglende repræsentation, men under den nationale afspænding siden 1950'erne har herbergstat og mindretal søgt alternative losninger. Et vigtigt element har her været etableringen af kontaktudvalg mellem regering, parlament og mindretal. I denne artikel skildrer forfatteren, hvorledes det tyske mindretal fik et sådant kontaktudvalg i 1965, og hvordan det fungerede indtil 1973.

\section{Staten og det tyske mindretal efter 1945}

Et afgørende led i normaliseringen af forholdet mellem dansk og tysk i den sønderjyske landsdel efter 1930'ernes og 1940'ernes nazisme, besættelse og retsopgør var en forbedring af relationerne mellem det tyske mindretal og dettes danske herbergsstat. I efterkrigstiden kom de tysksindede nordslesvigeres forhold flere gange til behandling på dansk regeringsniveau, hvor resultatet blev forbedringer i mindretallets situation. Første skridt var det såkaldte Københavnsnotat fra 1949, på tysk side benævnt Kopenhagener Protokoll. Uden at kunne sidestilles med den slesvig-holstenske landdags Kiel-erklæring fra samme år om de danske og frisiske befolkningsgruppers rettigheder i Sydslesvig afspejlede notatet, at mindretallets ledelse på ny blev anset for en samtalepartner af den danske regering. ${ }^{1}$ Det andet skridt blev taget med København-Bonn-Erklæringerne af 1955. Hovedresultatet for det tyske mindretal var en anerkendelse af mindretalsskolernes eksamensret. ${ }^{2}$ Det tredje skridt blev taget i 1964/65, da det tyske mindretal efter stemmetilbagegang mistede sit folketingsmandat og $\mathrm{i}$ 
stedet fik et kontaktudvalg. Denne ordnings tilblivelse og første virkeperiode er ikke tidligere blevet undersøgt på grundlag af primært arkivmateriale. ${ }^{3}$ Det er hensigten med denne artikel at råde bod på dette.

Kildegrundlaget for undersøgelsen er i første række akterne i Udenrigsministeriets arkiv om det tyske mindretals parlamentariske repræsentation. Det tyske mindretals forhold har altid haft en stærk udenrigspolitisk dimension, dels fordi det var vigtigt for Danmarks forhold til den store nabostat mod syd, dels fordi der i Sydslesvig var et dansk mindretal, hvis forhold til den slesvig-holstenske delstat og den tyske forbundsstat kunne påvirkes af den danske behandling af det tyske mindretal i Nordslesvig. Derfor fulgte Udenrigsministeriet udviklingen i grænselandet tæt, ikke mindst via generalkonsulatet i Flensborg, ligesom ministeriet altid blev inddraget af de andre ministerier i slesvigske mindretalsspørgsmål. Ofte var det i Udenrigsministeriet, at den egentlige sagsbehandling fandt sted. ${ }^{4}$

\section{Det tyske mindretals folketingsmandat}

Efter Genforeningen bestemtes ved lov af 30. august 1920, at de daværende fire sønderjyske amter ved folketingsvalg skulle udgøre én samlet amtskreds med syv kredsmandater, og at nye partier ikke som i det øvrige land skulle indsamle 10.000 underskrifter for at kunne opstille og få andel i tillægsmandaterne. Begge dele var vigtige for det tyske mindretal, som fik valgt en folketingsmand ved samtlige valg i mellemkrigstiden, hvor Slesvigsk Partis andel af stemmerne stabilt lå omkring 14-15 procent af stemmerne i amtskredsen. ${ }^{5}$ I 1943 stillede partiet ikke op, da mange af de mandlige vælgere gjorde fronttjeneste. I stedet blev der efter pres fra besættelsesmagten indrettet et særligt tysk kontor under Statsministeriet, der fik mindretallets propagandaleder Rudolf Stehr som leder. ${ }^{6}$ Kontoret blev nedlagt efter det tyske nederlag i maj 1945.

Efter Befrielsen blev det generelt et mantra i dansk mindretalspolitik, at alle særrettigheder skulle afskaffes. Det ramte også mindretallets muligheder for valgdeltagelse. ${ }^{7}$ Ved lov af 1 . oktober $1945 \mathrm{blev}$ den sønderjyske særregel fra 1920 ophævet. Herefter måtte Slesvigsk Parti indsamle 10.000 underskrifter for at opstille som parti. Eftersom partiet kun havde opnået over 10.000 stemmer ved tre ud af syv valg i mellemkrigstiden, var det i praksis en umulig opgave. Det forbed- 
rede ikke Slesvigsk Partis muligheder, at den sønderjyske amtskreds med valgloven af 9. juni 1948 mistede et kredsmandat. Reduktionen skyldtes den ret beskedne befolkningstilvækst i Nordslesvig og var som sådan ikke rettet særligt imod mindretallet, men den fik alligevel alvorlige konsekvenser for dette.

Ved efterkrigstidens første tre folketingsvalg opstillede mindretallet en kandidat uden for partierne, men det lykkedes hverken i 1947 for Waldemar Reuter, i 1950 for Hans Schmidt-Gorsblock eller i april 1953 for Hans Schmidt-Oxbüll at opnå stemmer nok til et kredsmandat. Stemmeandelen lå ved de tre valg på syv-ni procent. ${ }^{8}$

Medvirkende til det lave niveau i forhold til mellemkrigstiden var, at mange hjemmetyske vælgere $i$ en årrække mistede deres valgret, da de som led i retsopgøret fradømtes "almen tillid«. Ved lov af 27. maj 1950 blev valgretten imidlertid givet tilbage til de ca. 2.000 medlemmer af mindretallet, der ved retsopgøret var idømt to og et halvt års fængsel eller derunder. Da valglisterne først skulle ændres, fik mindretallet ikke gavn af dette før i april 1953, men trods en fremgang på lidt over 2.000 stemmer mislykkedes det, som nævnt, også denne gang at vinde et kredsmandat.

Så lysnede det endelig. Den 5. juni 1953 fik Danmark en ny grundlov, der forøgede antallet af folketingsmedlemmer fra 151 til 175 (foruden de fire nordatlantiske mandater). Den sønderjyske amtskreds fik igen tildelt syv kredsmandater. Ved det forste valg efter grundlovsændringen i september 1953 lykkedes det mindretallet at vinde et folketingsmandat. Hans Schmidt-Oxbüll fik som kandidat uden for partierne 9.721 stemmer, en fremgang på små 700 stemmer og det højeste siden 1939. Det rakte til et kredsmandat. Efter valget anmeldte Hans Schmidt sig i Folketinget som repræsentant for Slesvigsk Parti. ${ }^{9}$ Dermed var problemet med at samle de 10.000 underskrifter løst i det mindste ved det kommende valg. Det fandt sted i 1957, og mindretallet genvandt her mandatet med 9.202 stemmer. Det gentog sig 1960 med 9.047 stemmer. Stemmeandelen lå på otte-ti procent, men med faldende tendens. ${ }^{10}$

\section{Foreløbige overvejelser i Udenrigsministeriet}

Det vigende stemmetal kombineret med et stigende befolkningstal i Nordslesvig gjorde, at flere forud for folketingsvalget den 22. september 1964 forudså, at det tyske mindretals mandat ville gå tabt. 


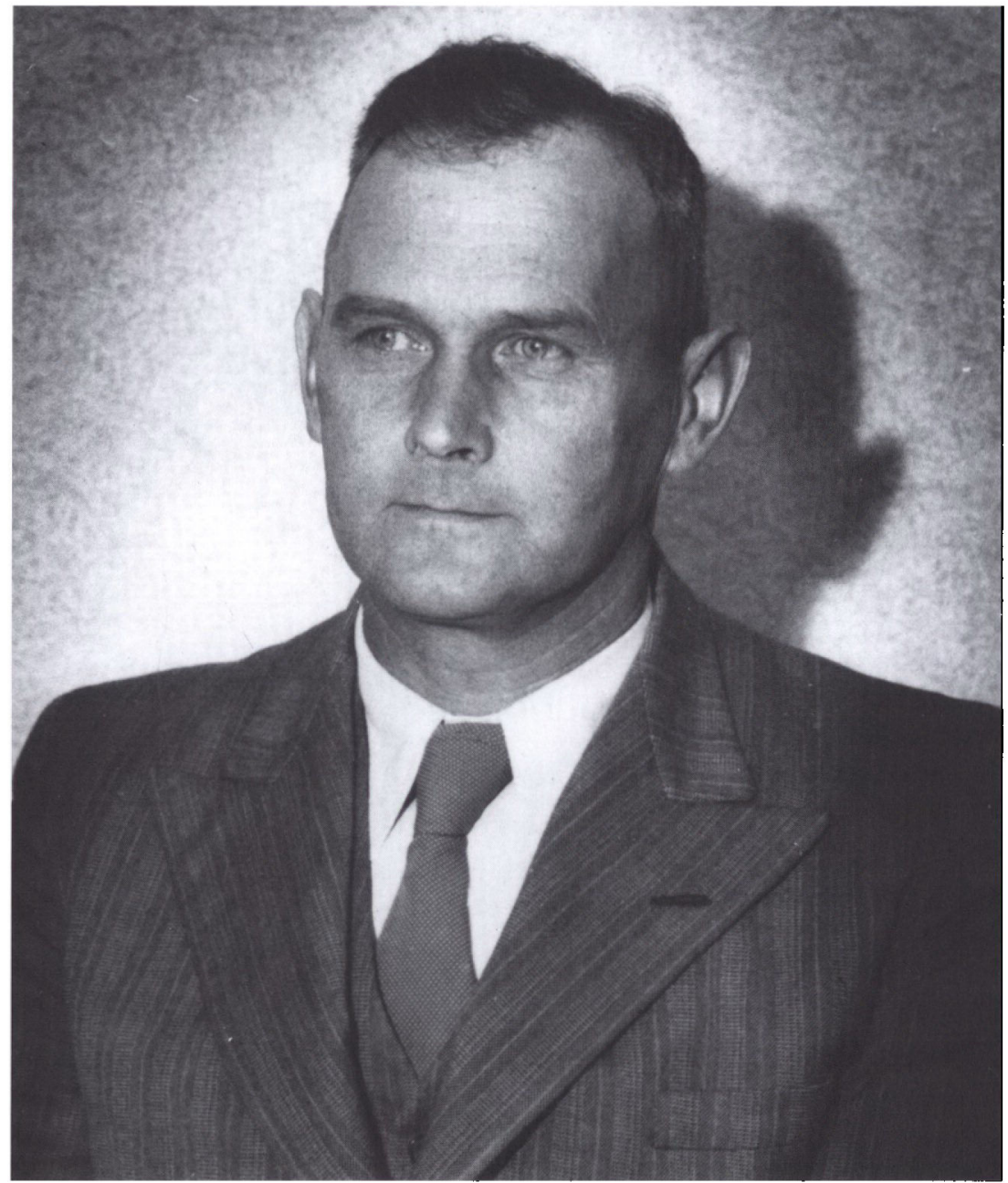

Hans Schmidt-Oxbüll (1899-1978), landmand fra Oksbol på Nordals, var 1951-60 formand for det tyske mindretals hovedorganisation Bund deutscher Nordschleswiger. I 1953 blev han valgt som den forste hjemmetyske folketingsmand efter 2. Verdenskrig. Hans vision var dannelsen af et dansk-tysk "arbejdsfallesskab" til sikring af grænselandets videre udvikling, men han formåde kun i ringe omfang at virkeliggore denne kongstanke. Foto i Museum Sonderjylland - ISL.

Muligheden herfor blev diskuteret i pressen, og alternativer blev drøftet. ${ }^{11}$

Også i Udenrigsministeriet beskæftigede man sig allerede før valget med, hvad der skulle ske, såfremt det tyske mandat gik tabt. 
Sekretær Flemming Mørch skrev den 11. august et fortroligt notat om mindretallets repræsentation i Folketinget og om en eventuel erstatning herfor. ${ }^{12}$ Han forudså, at de tyske nordslesvigere i tilfælde af mandatets bortfald ville kræve en ophævelse af valglovens to procent spærreklausul for mindretallets vedkommende.

For den rette forståelse af det følgende er det her nødvendigt at indskyde nogle oplysninger om spærregrænsen $i$ henhold til valglovens bestemmelser om tillægsmandater. De 175 folketingsmandater var og er stadig i 2011 fordelt på 135 kredsmandater og 40 tillægsmandater. De sidste har til formål at kompensere de partier, som har opnået for få kredsmandater set $\mathrm{i}$ forhold til den tænkte situation, at hele landet er én valgkreds. Meningen med tillægsmandaterne er således at sikre så retfærdig en repræsentation som muligt. For at få del i tillægsmandaterne skal et parti opfylde mindst én af følgende tre betingelser: at partiet har opnået mindst ét kredsmandat, eller at partiet $i$ to af de tre hovedområder, landet ved valg er opdelt $i$ (hovedstaden, øerne, Jylland) har opnået mindst lige så mange stemmer, som der $\mathrm{i}$ de pågældende områder $\mathrm{i}$ gennemsnit er afgivet pr. kredsmandat, eller at partiet $i$ hele landet har opnået mindst to procent af stemmerne.

Første betingelse var uaktuel for mindretallet; var der vundet et kredsmandat, var spørgsmålet om et tillægsmandat overflødigt, og mandat nummer to lå helt uden for det opnåelige. Anden betingelse lå ligeledes hinsides det mulige, eftersom Slesvigsk Partis stemmer alle faldt i det jyske hovedområde. Tredje betingelse var også umulig at opfylde, eftersom Slesvigsk Partis stemmeandel på landsplan lå på 0,35 procent. ${ }^{13}$ Her havde mindretallet dog med sit krav om en fritagelse for spærregrænsen "en god sag " $i$ og med, at det danske mindretal i Sydslesvig med København-Bonn-Erklæringerne fra 1955 havde opnået fritagelse for den slesvig-holstenske valglovs spærregrænse på fem procent og dermed fået adgang til repræsentation $\mathrm{i}$ landdagen. Her kunne de tyske nordslesvigere håbe på den gensidighedsmekanisme, som ofte før havde udøvet sin virkning i grænselandet. En ophævelse ville føre til det ønskede resultat, eftersom det billigste tillægsmandat ved valget i 1960 i det jyske område kun kostede godt 5.300 stemmer, altså omkring 3.700 stemmer under Slesvigsk Partis resultat dette år.

Sekretær Mørch fandt imidlertid, at en ophævelse ville være uforenelig med grundlovens princip om ligelighed i repræsentationen, idet 
den ville føre til en favorisering af Slesvigsk Parti sammenlignet med andre småpartier. I stedet foreslog Mørch nedsættelsen af et udvalg bestående af repræsentanter for Folketingets partier og mindretallet: "Tyskerne skulle for dette forum kunne fremføre de spørgsmål, som var af særlig interesse for dem, og i det hele holdes nogenlunde løbende orienteret om arbejdet $i$ tinget særlig med henblik på foranstaltninger vedrørende det sønderjyske område«. Et sådant udvalg havde et fortilfælde i grænselandet. Da Sydslesvigsk Vælgerforening ved landdagsvalget i 1954 kom under spærregrænsen i Slesvig-Holsten på fem procent, blev der i tilknytning til landdagen nedsat et rådgivende udvalg med repræsentanter for landdagens partier og to for SSW, indtil SSW i 1958 på ny opnåede plads i landdagen. ${ }^{14}$ Gensidighedsmekanismen kunne altså pege på andre løsningsmuligheder end en dansk ophævelse af spærreklausulen på de to procent. Der var også andre argumenter for et udvalg: Det kunne nedsættes af Folketinget uden videre formaliteter, det ville give mindretallet en politisk medindflydelse "på en måde, som næppe kunne fremkalde betænkeligheder «, og det var i pagt med dansk demokratisk tradition at give mindretallet mulighed for at blive hørt, skønt det kun udgjorde omkring 9.000 vælgere.

Mulige forslag om en mindretalsobservatør med taleret i Folketinget afviste Mørch som uforenelige med grundloven, medmindre der blev udpeget en særlig minister for mindretallet. En tilsvarende observatørordning for SSW var i øvrigt i sin tid blevet afvist af såvel den tyske forbundsregering som den slesvig-holstenske delstatsregering.

Mørchs notat cirkulerede internt i Udenrigsministeriet. Daværende fuldmægtig, senere ambassadør, Ole Bierring understregede den 14. august i et tillæg til Mørchs notat "Danmarks traditionelle og til stadighed fastholdte modvilje mod at tilstå det nationale mindretal særrettigheder ${ }^{15}{ }^{15}$ Han fremhævede: "Det tyske mindretal er inde $\mathrm{i}$ en med den fremadskridende afsvækkelse af de nationale modsætningsforhold i grænselandet naturlig udvikling i nedadgående retning, og da man antagelig før eller senere må konstatere, at tilslutningen til mindretallet er så ringe, at en repræsentation ikke er rimelig, taler meget efter mit skøn for at gøre holdt allerede nu«. Bierring ville med andre ord undgå ordninger, der kun ville give en løsning på kort sigt. Han var enig med Mørch i, at nedsættelsen af et "kontaktorgan " ville være det bedste. Ganske vist gav det mindretallet en særrettighed, men "på baggrund af den udvikling, der har fundet sted siden for- 
handlingerne i 1955 « havde han ikke betænkeligheder derved. Bierring advarede dog mod, at organet fik et navn, der kunne lede tanken hen på det tyske kontor i Statsministeriet under besættelsen. I et PS fremhævede han, at initiativet måtte ligge hos mindretallet.

Generalkonsul Troels Fink i Flensborg fik Mørchs notat med Bierrings kommentarer forelagt. Fink erklærede sig den 2. september enig $i$, at initiativet $i$ givet fald måtte komme fra mindretallet. Han bragte et nyt moment på banen, nemlig whvis der bliver tale om f.eks. et kontaktudvalg, kan opnås en parallel ordning for det danske mindretal syd for grænsen i forhold til Bonn«. SSW havde mistet sin plads i forbundsdagen i 1953, uden at der var tilvejebragt nogen form for erstatning for det tabte mandat. ${ }^{16}$

\section{Det tyske folketingsmandat går tabt - reaktioner i København, Nordslesvig og Kiel}

Ved valget den 22. september 1964 indtraf det forudsete. Slesvigsk Parti fik trods en lille fremgang på et par hundrede stemmer til 9.274 ikke vælgertilslutning nok til at bevare kredsmandatet. Det havde krævet 11.592 stemmer. Årsagen lå dels i befolkningstilvæksten, dels i nedsættelsen i 1961 af valgretsalderen fra 23 til 21 år. Ingen af delene gavnede datidens isolerede mindretal, der havde en svag tilslutning blandt de unge. Derimod havde mindretallet haft stemmer nok til et tillægsmandat, som kunne fås for ca. 7.700 stemmer - hvis det ikke havde været for spærregrænsen på de to procent. ${ }^{17}$

Den vragede folketingsmand for Slesvigsk Parti, Hans Schmidt, henvendte sig den 6. oktober 1964 til Folketingets formand og præsidium og Socialdemokratiets gruppeformand. Her anmodede han som formand for Slesvigsk Parti om, at et eksisterende uformelt "udvalg for anliggender vedr. Slesvigsk Parti«, som var oprettet i maj 1959 og bestod af partiernes gruppeformænd, de sønderjyske folketingsmedlemmer og repræsentanter for Slesvigsk Parti, nu ved en folketingsbeslutning fik tildelt en formel status som en midlertidig forbindelse mellem Slesvigsk Parti og Folketinget. ${ }^{18}$

Samme dag udtalte statsminister Jens Otto Krag i sin åbningstale: »De problemer, som følger af, at det tyske mindretal efter valget ikke længere er repræsenteret i Folketinget, vil regeringen efter nærmere forhandling søge løst på en for mindretallet tilfredsstillende måde «. ${ }^{19}$ Det tyske mindretal blev indbudt til forhandling i Kobenhavn den 26. 


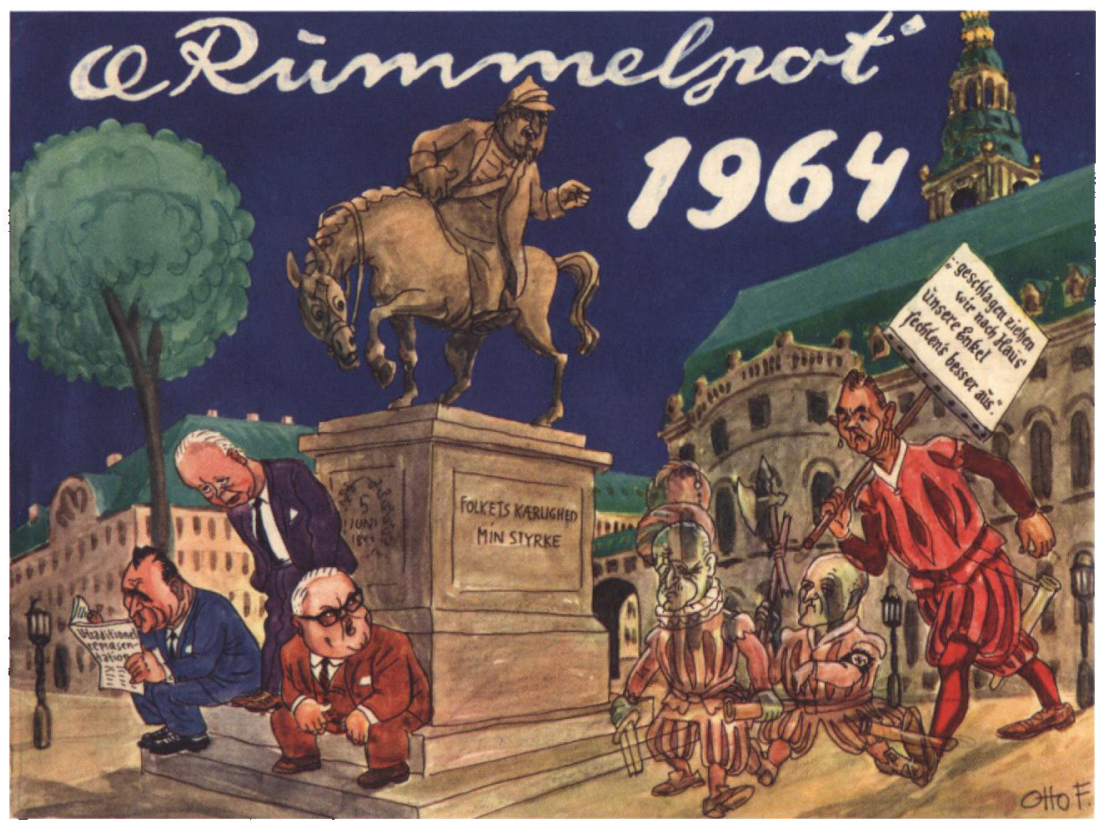

Ved folketingsvalget $i$ september 1964 mistede det tyske mindretal sin repræsentation på Christiansborg. Denne begivenhed prydede Otto Frederiksens forside på årets udgave af "æ Rummelpot". Til højre ses den garderhoje Hans Schmidt forladende Christiansborg som fhv. MF. Foran ham går som to spøgelsesskikkelser forgængerne, pastor Johannes Schmidt-Wodder og dyrlæge Jens Möller, sidstnæonte med naziarmbind. Frederik 7. ser til fra sin rytterstatue. Ved statuens fod sidder de tre vragede kandidater fra mindretallet. Fra venstre er det Harro Marquardsen, Jef Blume og Jes Schmidt. Marquardsen læser ivrigt $i$ et skrift med titlen "utraditionel repræsentation $"$.

oktober 1964 - samme dag som ledende danske sydslesvigere mødtes med regeringen.

Forinden blev det tyske mindretals ledelse inviteret til forhandling $i$ Kiel den 13. oktober 1964 af den slesvig-holstenske ministerpræsident Helmut Lemke. Her fandt man, at det danske mindretals rettigheder i Slesvig-Holsten kunne udgøre et godt grundlag for mindretallets drøftelse med den danske regering. ${ }^{20}$

Spørgsmålet om mindretallets politiske repræsentation kaldte også på stillingtagen fra de sønderjyske folketingspolitikere og landsdelens nationalt interesserede kredse. I den danske sønderjyske presse var der ingen, der hoverede over mindretallets tab af mandatet, og man gav sin tilslutning til statsministerens udtalelse. ${ }^{21}$ Blandt de få, der 


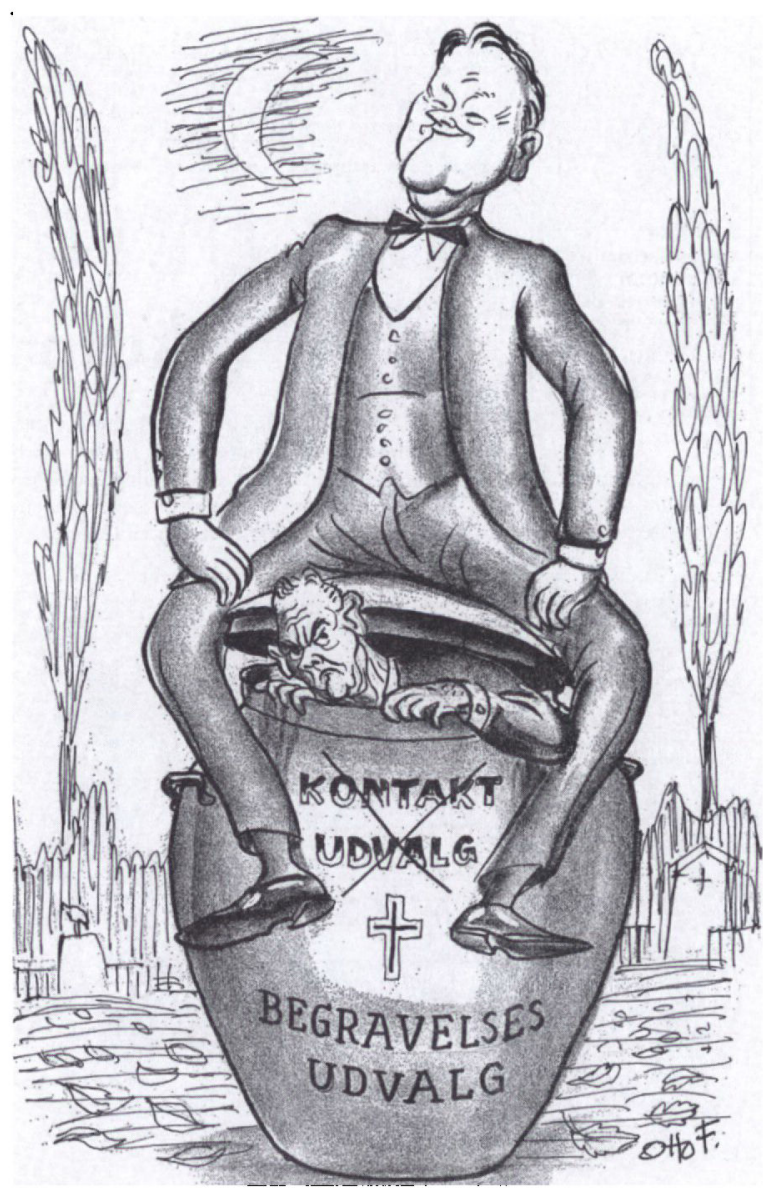

Blandt de kritiske roster mod kontaktudvalgsordningen var Hans Schmidt-Oxbüll. Han frygtede, at udvalget ville blive et »begravelsesudvalg ", hoor mindretallets problemer ville blive syltet. På Otto Frederiksens tegning $i$ "æ Rummelpot « 1965 ses Schmidt $i$ urnen med statsminister Jens Otto Krag siddende på låget.

ytrede sig, var den nyvalgte konservative folketingsmand - og senere statsminister - Poul Schlüter, der mente, at det mistede folketingsmandat ikke var noget stort tab for mindretallet. Mindretallet havde ikke været henvist til at tilkæmpe sig sine rettigheder gennem politisk arbejde på tinge, men fået dem tildelt $\mathrm{i}$ overensstemmelse med Danmarks demokratiske traditioner, og der var ingen grund til at frygte for deres fortsatte beståen. Mindretallets stilling var helt den samme 
efter som før valget. Skulle særlige problemer opstå for mindretallet, ville de andre sønderjyske folketingsmænd utvivlsomt påtage sig at søge dem løst i samarbejde med regering og centraladministration, og mindretallet havde stadig sine amtsråds- og kommunalbestyrelsesmedlemmer. Sandt at sige havde folketingsmandatet i de senere år mest været et statussymbol for mindretallet. Der var ifølge Schlüter intet behov for en særordning. ${ }^{22}$

Schlüter var imidlertid den eneste kritiske røst, $i$ hvert fald $i$ offentligheden. De andre sønderjyske politikere synes at have givet deres tilslutning til kontaktudvalgsløsningen. Også de nationale foreninger lod sagen gå sin stille gang. De sønderjydske Danske Samfunds formand Jes Caspersen fandt, at ingen kunne have noget imod, at et mindretal af en størrelse som det tyske fik en særlig adgang til at føre sager frem for Folketinget og regeringen. Blot mente han, at der burde være fuld offentlighed om udvalgets arbejde, så dette ikke i det skjulte udviklede sig til en pressionsgruppe. ${ }^{23}$

Reaktionerne på det tyske mindretals tab af folketingsmandatet tydede samlet set ikke på, at det skulle blive særligt vanskeligt at finde en løsning.

\section{Forhandlinger mellem mindretal og regering}

Forud for regeringens møde med mindretallet beskæftigede Udenrigsministeriet sig på ny med mindretallets politiske repræsentation. ${ }^{24}$ Ole Bierring forventede $i$ et notat af 21 . oktober 1964, at mindretallet her og nu ville kræve oprettelse af et kontakt- eller forhandlingsudvalg til erstatning af det tabte mandat og dernæst en ændring af valgloven, så Slesvigsk Parti blev fritaget for kravet om 10.000 underskrifter som betingelse for opstilling som parti samt for to procent spærregrænsen som betingelse for at kunne opnå tillægsmandater. Bierring tilrådede, at regeringen viste sig imødekommende med hensyn til kontaktudvalget, men henviste de andre krav til drøftelse i udvalget, når det til sin tid var dannet.

Kontakt- eller forhandlingsudvalget skulle nedsættes af statsministeren. En minister skulle være formand. De menige medlemmer skulle dels være repræsentanter for Folketingets udvalgsberettigede partier, dels tre repræsentanter valgt af mindretallets hovedorganisation Bund deutscher Nordschleswiger. Sekretæren burde være en dansk embedsmand. Han skulle alene indkalde til møderne og føre 
protokol. Bierring afviste klart et permanent kontor i København med en leder ansat af mindretallet, men lonnet af staten. Det mindede for meget om det tyske kontor under besættelsen.

Med hensyn til det danske mindretals repræsentation ved et udvalg ved Forbundsdagen i Bonn mente Bierring, at en sammenkædning burde undgås, sidet man fra dansk side med bestemthed bør fastholde sit standpunkt om, at man ikke ønsker noget, der blot på mindste måde kunne tydes som en dansk-tysk aftale om mindretalsspørgsmål«. På dette punkt skræmte sporene fra Det tyske Forbunds mange interventioner i det danske monarkis forhold i 1800-tallet altså stadig - endnu en halv snes år efter København-Bonn-Erklæringerne. ${ }^{25}$ De danske sydslesvigere måtte derfor selv tilkæmpe sig et sådant udvalg. Bierring tilrådede dog, at det afventede en afklaring for det tyske mindretal - så gensidighedsmekanismens eksistens erkendte han altså alligevel.

Nok så overraskende var, at Bierring på Udenrigsministeriets vegne også tilrådede dansk imødekommenhed med de 10.000 underskrifter og to procent spærreklausulen. Han erkendte, at den danske position politisk var svag, eftersom Slesvig-Holsten havde ophævet fem procent spærreklausulen for nationale mindretal.

Mødet med det tyske mindretal fandt sted den 26. oktober 1964. Forud var samme dag gået et møde med repræsentanter for det danske mindretal i Sydslesvig, hvor det tyske mindretals problemer også blev berørt. De danske ledere syd for grænsen fremhævede: "Det var et hovedsynspunkt fra sydslesvigsk side, at man gerne så de rettigheder, som det danske mindretal gennem årene havde kæmpet for, tillagt også andre mindretal «. I situationen fandt man, at det skete bedst for det tyske mindretal ved oprettelsen af et kontaktudvalg. Det danske mindretal ville nærmere overveje, om et sådant kontaktudvalg kunne bane vejen for et tilsvarende i Bonn. ${ }^{26}$

I mødet mellem regeringen og det tyske mindretal deltog ikke mindre end syv ministre. ${ }^{27}$ Foruden statsminister Jens Otto Krag var det udenrigsminister Per Hækkerup, finansminister Poul Hansen, indenrigsminister Hans Hækkerup, socialminister Kaj Bundvad, undervisningsminister K.B. Andersen og kulturminister Hans Sølvhøj. Mindretallets problemer blev i hvert fald taget alvorligt! Fra centraladministrationen deltog departementschef J. Elkjær Larsen og ministersekretær Helge Hjortdal fra Statsministeriet, viceudenrigsråd Troels Oldenburg fra Udenrigsministeriet og kontorchef Palle Boel- 
skov fra Undervisningsministeriet. Mindretallets delegation bestod af gårdejer Harro Marquardsen, formand for Bund deutscher Nordschleswiger, samt redaktør Jes Schmidt, lærer Jef Blume og generalsekretær Rudolph Stehr.

Efter indledende udveksling af høfligheder fremlagde sidstnævnte mindretallets forhandlingsskitse. Den bestod ganske som ventet af to krav, dels en løsning på længere sigt, dels en overgangsløsning. Den langsigtede løsning skulle nås ved ændring af valgloven, så kravet om 10.000 underskrifter for at opstille som parti og spærregrænsen på to proccent blev ophævet for nationale mindretal. Mindretallet havde - ganske korrekt - beregnet, at det kunne have beholdt sit mandat, hvis det ikke havde været for spærregrænsen. Overgangsløsningen skulle være et udvalg under Statsministeriet med statsministeren som formand, en anden minister som stedfortrædende formand, repræsentanter for de udvalgsberettigede partier samt to til fire fra mindretallet. Udvalget skulle mødes mindst to gange i hvert folketingsår samt efter behov. Dets arbejde skulle koordineres af et sekretariat med kontor på Christiansborg, som skulle opretholde den daglige kontakt til Folketinget og centraladministrationen. Udgifterne skulle bæres af statskassen. Af den skriftligt fremlagte forhandlingsskitse fremgik, at sekretariatet skulle ledes af »en af mindretallet udpeget sekretær«.

Statsministeren mente, at Stehrs fremlæggelse udmærket kunne danne grundlag for regeringens overvejelser og drøftelser med partierne, men tog i øvrigt ikke stilling til de enkelte punkter. I stedet stillede han et nyt møde i udsigt. Marquardsen erklærede sig villig til et nyt møde og fremdrog det stående spørgsmål om de medlemmer af mindretallet, der havde været $\mathrm{i}$ offentlig tjeneste, men havde mistet deres pensionsrettigheder som følge af deres adfærd under besættelsen; det gjaldt især lærere i de tyske kommuneskoler, som var kommet i klemme under retsopgøret. Krag henviste til, at det netop var sådanne spørgsmål, som det kommende udvalg kunne tage op, og $\mathrm{i}$ så fald ville mindretallet jo sidde med ved forhandlingsbordet.

I Statsministeriet foretrak man efter mødet en nedsættelse af et udvalg benævnt »kontaktudvalg « med en minister som formand og to repræsentanter for hvert af de udvalgsberettigede partier samt repræsentanter for mindretallet. ${ }^{28}$ Så langt var man rede til at imødekomme mindretallets ønsker. En knast udgjorde derimod mindretallets ønske om en af mindretallet udpeget sekretær for udvalget. "Mindretallet 
tænker sig formentlig en tysksindet sekretær (hr. Stehr?)«, forestillede man sig og fandt: »En sådan ordning forekommer imidlertid at minde for meget om ordningen under besættelsen, hvor hr. Stehr havde et eget kontor under statsministeriet«. For så vidt havde mindretallet næppe gjort sig selv en tjeneste ved at give Stehr så fremtrædende en rolle i forhandlingerne. Dog var ønsket næppe blevet imødekommet under nogen omstændigheder, siden det allerede var afvist i Udenrigsministeriet. Statsministeriet henviste til, at det landdagsudvalg, som blev nedsat i Kiel i 1955, tilsvarende ikke havde en dansksindet sekretær. ${ }^{29} \mathrm{I}$ øvrigt ville et sekretariat på Christiansborg med en leder fra mindretallet give dette en særstatus, nærmest en "statsautorisation«, som lå langt over, hvad andre organiserede og større grupper havde. Det ville også være en meget dyr løsning. I stedet pegede ministeriet på en dansk embedsmand som sekretær.

Statsministeriet beskæftigede sig også med, hvilket folketingsmateriale udvalget kunne få til sin rådighed og mente, at det som andre ikke-repræsenterede partier måtte nøjes med det offentligt tilgængelige materiale. Ministeriet foreslog, at dette blev sendt direkte til mindretallets generalsekretariat: »Ved en sådan ordning opnås, at udvalget, ikke sekretæren, bliver det centrale $\mathrm{i}$ ordningen«.

Da Statsministeriet havde fastlagt sin politik, diskuterede statsministeren spørgsmålet med repræsentanter for partierne. ${ }^{30}$ Det skete den 19. november 1964. Her oplyste han, at statsministeren skulle være formand, indenrigsministeren næstformand og en embedsmand fra Indenrigsministeriet sekretær. Partierne gav principiel tilslutning til Statsministeriets skitse. Man lagde vægt på, at ordningen kunne accepteres i Sønderjylland, det vil sige i den danske flertalsbefolkning. Der blev peget på »risikoen for, at det tyske mindretal kunne skabe uoverensstemmelser og modsætningsforhold mellem de danske partier i udvalget, hvilket der var enighed om at søge undgået«. Udvalget måtte altså ikke bruges til partipolitisk markering på bekostning af dansk enighed. ${ }^{31}$ Antagelig har vi her kimen til den senere tradition med et rent dansk formøde forud for møderne med BdN's repræsentanter. ${ }^{32}$ Drøftelsen i partigrupperne synes ikke at have afstedkommet onsker om ændringer.

Spørgsmålet om kontaktudvalget blev også berørt af den tyske ambassadør, da denne i anden anledning havde et møde med Troels Oldenburg fra Udenrigsministeriet. Her fremlagde Oldenburg tankerne om et kontaktudvalg med en dansk sekretær. »Tanken om en tysk se- 
kretær ville næppe vinde genklang hos regeringen, da man kunne befrygte, at dette i befolkningen ville fremkalde mindet om det særlige tyske kontor, der blev oprettet under besættelsen «. Ambassadøren tog Oldenburgs bemærkninger til efterretning uden kommentar. Herefter var der også, uden at der fra dansk side var blevet bedt om det, givet grønt lys fra Bonn til den af Statsministeriet skitserede ordning. ${ }^{33}$

\section{Mindretallets stilling til forhandlingsresultaterne}

Bund deutscher Nordschleswiger tog stilling til de foreløbige forhandlingsresultater på sin generalforsamling den 13. januar $1965 \mathrm{i}$ Tinglev. Det skete i form af en resolution, hvor $88 \%$ af de delegerede tilsluttede sig tanken om et statsministerielt udvalg som en overgangsløsning, men fastholdt ønsket om et fast sekretariat i København med en leder fra mindretallet. Den varige løsning måtte være en genindførelse af bestemmelsen fra 1920, der fritog partier i de sønderjyske landsdele for kravet om 10.000 underskrifter for at stille op, samt en ophævelse af to procent spærregrænsen. Mindretallet burde være repræsenteret på tinge, så længe det havde stemmer nok til at opnå det »billigste« kredsmandat. ${ }^{34}$

Repræsentanter for Bund deutscher Nordschleswiger redegjorde for forhandlingerne på et møde i bestyrelsen for Grenzpolitischer Rat den 23. januar 1965. Rådet var et koordineringsorgan for slesvig-holstenske grænselandsorganisationer med deltagelse af embedsmænd og politikere. Forbundsdagsmedlem for CDU Will Rasner fremdrog her, at sekretæren for det kommende kontaktudvalg måtte være en dansk embedsmand med loyalitetsforpligtelse over for statsministeren; en ordning med en sekretær udpeget af mindretallet var således »ikke tænkelig “, og i Kiel eller Bonn ville en sådan ordning slet ikke komme til diskussion. Rudolph Stehr medgav, at man ikke med rimelighed kunne forlange af danskerne, at de skulle acceptere en sekretær, de ikke kunne have absolut tillid til. Mindretallets krav om at udpege sekretæren for kontaktudvalget var således ikke alene urealistisk, fordi en sådan ordning ville minde danskerne om det tyske kontor under besættelsen, men også fordi det stred imod statsmagtens almindelige loyalitetskrav. Og det indså mindretallets ledelse altså. ${ }^{35}$

Den 1. februar 1965 mødtes mindretallet og regeringen på ny. ${ }^{36}$ Her fik mindretallets repræsentanter forelagt regeringens af partierne godkendte forslag til forretningsorden for kontaktudvalget. Dette 
skulle bestå af statsministeren som formand og indenrigsministeren som stedfortræder, to medlemmer fra hver af Folketingets udvalgsberettigede partier samt tre repræsentanter fra BdN. Udvalget skulle mødes efter behov, dog mindst to gange hvert folketingsår, samt når mindst tre medlemmer krævede det. Statsministeren afviste under mødet kravet om et stående sekretariat med en leder fra mindretallet og fastholdt, at en dansk embedsmand skulle være sekretær. Spørgsmål om valgloven og pensionssagen blev henvist til første møde i kontaktudvalget. Mindretallet opnåede to tilføjelser: at der en gang årligt skulle afgives en beretning om udvalgets arbejde til Folketinget, samt at forhandlingerne var fortrolige, når det drejede sig om sager af personlig karakter.

BdN tog stilling til det endelige resultat af forhandlingerne i en resolution fra et delegeretmøde i Tinglev den 9. marts $1965 .{ }^{37}$ Man fandt forretningsordenen tilfredsstillende, om end man beklagede, at ønsket om et fast sekretariat med en leder fra mindretallet ikke var blevet opfyldt. Delegeret-forsamlingen tiltrådte forhandlingsresultatet, men med forbehold for, at spørgsmålet om ændringer i valgloven snarest ville blive diskuteret $i$ kontaktudvalget, og såfremt resultatet heraf ikke blev tilfredsstillende for mindretallet, forbeholdt de delegerede sig "udtrykkeligt " at tage sagen op til "fornyet principiel vurdering«. Det sidste kunne tolkes som en trussel om at trække tæppet væk under kontaktudvalget, såfremt valglovsforhandlingerne skulle gå Slesvigsk Parti imod. Det var næppe særlig velovervejet, eftersom mindretallet havde mest at miste, hvis udvalget faldt bort, men måske var forbeholdet en indrømmelse til interne kritikere for at opnå størst mulig tilslutning. ${ }^{38}$ Resolutionen blev i hvert fald antaget med 215 ud af 220 stemmer. $^{39}$ At der var utilfredshed med ordningen hos nogle i mindretallet, fremgår af Harro Marquardsens bemærkninger på det forste møde i kontaktudvalget i maj samme år, hvor han "ikke ville skjule, at der findes kredse, der betragter udvalget og dets arbejdsmuligheder med skepsis « ${ }^{40}$

Resolutionen sluttede imidlertid forsonligt med ønsket om, at udvalget blev »et effektivt kontaktorgan, og at det i overensstemmelse med den gensidige vilje til forståelse må blive til gavn for hele grænselandet og det dansk-tyske forhold «. Delegeretforsamlingen foreslog som medlemmer BdN's formand, gårdejer og amtsrådsmedlem Harro Marquardsen, Faverby, sammen med chefredaktør Jes Schmidt og skolekonsulent Arthur Lessow, begge Aabenraa. 
Få dage senere, den 12. april, blev resultatet fremlagt og drøftet $\mathrm{i}$ Grenzpolitischer Rat. Stehr fremlagde her kontaktudvalgets forretningsorden og hæftede sig navnlig ved en "storsindet ordning af kompetencespørgsmålet «, der muliggjorde, at alle emner bortset fra udenrigspolitik kunne tages op. Ligeså positivt var ifølge Stehr, at statsministeren havde overtaget formandskabet og dermed givet udvalget en særlig vægt. Afvisningen af mindretallets krav om et tysk sekretariat tog Stehr med henvisning til diskussionen herom på det forrige møde $i$ rådet til efterretning. Alt $i$ alt var Stehr således godt tilfreds med resultatet. Ved samme lejlighed foreslog han oprettelsen af et kontaktudvalg ved den slesvig-holstenske landdag, der skulle varetage kontakten til mindretallet $\mathrm{i}$ Nordslesvig. Med tiden kunne de to kontaktudvalg måske mødes. ${ }^{41}$

Med BdN's accept af statsministerens tilbud var kontaktudvalget en realitet. Set fra mindretallet var der imidlertid kun opnået en delløsning på problemet om dets parlamentariske repræsentation. Kontaktudvalget var i denne optik kun en midlertidig løsning. Det skulle præge forhandlingerne i udvalget i den forste tid, som der her skal gives et overblik over på grundlag af udvalgets mødereferater.

\section{Kontaktudvalgets arbejde 1964-1973: Parlamentarisk repræsentation og pensionsrettigheder}

Mindretallets parlamentariske repræsentation var således straks fra det første møde i kontaktudvalget i maj 1965 og igennem hele den her behandlede periode et hovedpunkt på dagsordenen. Harro Marquardsen ytrede her skuffelse over, at der ikke var taget hensyn til mindretallet $i$ forslaget til en ny valglov. Indenrigsministeren kunne meddele, at de danske medlemmer af udvalget så med afgjort sympati på at fritage mindretallet for kravet om at indsamle 10.000 underskrifter for at stille op ved folketingsvalg, hvorimod der ikke var stemning blandt de danske partier for at ophæve to procent spærregrænsen for mindretallets vedkommende. Der var med andre ord udsigt til en delvis imødekommelse af mindretallets ønsker. BdN's repræsentanter fandt imidlertid, at det første jo ikke nyttede meget, hvis ikke det andet fulgte med. ${ }^{42}$ Fritagelsen for indsamling af 10.000 underskrifter blev gennemført ved ændringen af folketingsvalgloven af 21 . december $1965 .^{43}$

Mindretallets forsøg på at opnå fritagelse for spærregrænsen fort- 
satte. På mødet i maj 1966 gav det anledning til en mindre kontrovers. Fra generalkonsulatet i Flensborg havde indenrigsministeren fået oplyst, at mindretallets ledere havde haft et møde med CDU-fraktionen i den slesvig-holstenske landdag, hvor fraktionsnæstformanden Herbert Gerisch havde udtalt, at man burde støtte mindretallets krav og tilskynde til en drøftelse af sagen mellem den danske regering og den slesvig-holstenske delstatsregering. Det var de danske medlemmer af udvalget blevet "noget forundrede" over. Marquardsen benægtede, at mindretallet havde søgt hjælp sydpå. Der var blot tale om et orienterende møde med de slesvig-holstenske partier. "Det havde absolut ikke været hensigten at søge at få landsregeringen i Slesvig-Holsten til at optage forhandlinger med den danske regering «, bedyrede han. Jes Schmidt indså, at der kunne rejses tvivl om mindretallets loyalitetserklæring, dersom indberetningen havde været rigtig, og understregede, "at der ingen anledning var til at tvivle om mindretallets loyalitet overfor de danske myndigheder og det danske folk. Det ville på ingen måde prove at få myndighederne $\mathrm{i}$ andre lande til at intervenere i spørgsmål, der vedrører forholdet mellem mindretallet og det danske samfund «. Indenrigsministeren udtalte, »at det tyske mindretal havde en legitim ret til at kontakte moderland og myndigheder dér", og fortsatte: »indberetningen rystede os, men vi tager det fremførte til efterretning “. ${ }^{44}$ Det kan tilføjes, at der nu om dage skal væsentligt mere til at ryste danske og tyske grænselandspolitikere. Rammerne for, hvad et nationalt mindretal kan få sit moderland til at foretage sig på dette punkt, synes væsentligt udvidet siden 1966. Det viser danske politikeres støtte til de danske sydslesvigere $\mathrm{i}$ forbindelse med delstatsregeringens nedskæring af tilskuddet til de danske mindretalsskoler i $2010 .{ }^{45}$

Spærregrænsen kom atter på kontaktudvalgets dagsorden i 1967 og 1968, uden at der fremkom nye synspunkter fra nogen af siderne. I 1971 foreslog Marquardsen indførelse af andenstemmer svarende til tyske forhold. Dette stillede indenrigsministeren sig meget tvivlende overfor og forslaget fik ingen gang på jorden. Jes Schmidt henviste til, at det danske mindretal syd for grænsen, hvis stemmetal dengang var for nedadgående, om føje tid sandsynligvis ville miste sit mandat i landdagen, og at denne situation måske kunne åbne for en ny løsning både nord og syd for grænsen. ${ }^{46}$ Her gjorde han som bekendt regning uden vært. Spørgsmålet blev atter drøftet i marts 1972. Mindretallet fremførte da på ny, at det danske mindretal syd for grænsen 
var fritaget for den slesvig-holstenske spærregrænse på fem procent. Gorrsen bemærkede, »at når man vil drage sammenligninger mellem de danske og tyske valgordninger, da må man sammenligne forbundsdagen i Bonn med folketinget i København og landdagen i Kiel med amtsrådet i Sønderjylland. Kun i disse relationer er en sammenligning rimelig ${ }^{4} .{ }^{47}$ Dermed udtalte Gorrsen et kernepunkt i den danske opfattelse af, hvem der stod lige med hvem i de dansk-tyske mindretalsspørgsmål. Det var i fuld overensstemmelse med folkeretten, men tog ikke videre hensyn til de store forskelle i befolkningstallene på de respektive niveauer.

Med hensyn til spærregrænsen løb mindretallet således vedvarende panden imod en enig dansk mur. Problemet fandt sin losning ad anden vej. Da partiet Centrum-Demokraterne opstod i 1973, indgik det et samarbejde med Slesvigsk Parti om opstilling af redaktør Jes Schmidt på CD's liste, og det lykkedes ham at blive valgt ved det såkaldte "jordskredsvalg“ i december 1973. Han blev således den tredje Schmidt til at repræsentere mindretallet på tinge - efter Johs. Schmidt-Wodder og Hans Schmidt-Oxbüll. Dermed var spørgsmålet om mindretallets politiske repræsentation løst, $i$ hvert fald for en tid.

Et nyt aspekt af repræsentationsproblemet opstod med sammenlægningen af de fire sønderjyske amter til Sønderjyllands Amt i 1970. Mindretallet ønskede medlemstallet $i$ det nye sønderjyske amtsråd fastsat til 27 i stedet for de 25 , som man var blevet enige om i fællesudvalget. Derved ville mindretallet få bedre chancer for at få to mandater $\mathbf{i}$ stedet for ét. De 25 blev imidlertid fastholdt af kommunalreformkommissionen, og ved det første amtsrådsvalg i 1970 måtte Slesvigsk Parti nøjes med én repræsentant $\mathrm{i}$ amtsrådet. I $1974 \mathrm{blev}$ medlemstallet $\mathrm{i}$ amtsrådet øget ikke til 27, men 29, og ved valget dette år fik Slesvigsk Parti da også to mandater. Trods udvidelsen fik partiet imidlertid kun et enkelt mandat ved de følgende valg. ${ }^{48}$

En hurtig og varig løsning fandt udvalget på mindretallets anden store sag, tilbagegivelsen af pensionsrettigheder til medlemmer, der som følge af retsopgøret efter Besættelsen havde mistet deres pensionsret som tjenestemænd enten i staten, skolevæsnet eller kommunerne. Dette krav havde stået meget højt på mindretallets politiske dagsorden gennem mange år. Det blev nu næsten fuldstændigt imødekommet ved forhandlingerne i kontaktudvalget 1965/66. Fra dansk side ville man ikke gå med til at tilbagegive pensionsretten til fhv. overløjtnant Peter Larsen fra Løjt Skovby, som ved retsopgøret var idømt en 
straf på 13 års fængsel, og som dermed var en af de mest belastede fra mindretallet. Det kunne Marquardsen godt forstå. Men ellers genvandt $i$ alt 16 personer, som tidligere havde været ansat i staten eller skolevæsnet - eller deres enker - deres pensionsret, om end det ikke $i$ alle tilfælde førte til en forhøjet pension. ${ }^{49}$ Dermed var der også udsigt til, at problemet ville blive løst for afskedigede kommunale tjenestemænd. Afslutningen på pensionssagen var en gevinst for alle parter. De berørte personer fik forbedret deres økonomi. Mindretallets ledelse, som havde satset nærmest uforståelig megen politisk energi og prestige på sagen, opnåede en intern styrkelse over for de kredse, som endnu tyve år efter krigen stivnede i kronisk utilfredshed med retsopgøret. Mindretallet som helhed opnåede den - formentlig dengang uerkendte - fordel, at dette spørgsmål ikke længere forbandt det med nazitiden. På dansk side kunne man glæde sig over, at et irriterende konfliktpunkt var ryddet af vejen. Og kontaktudvalget havde på et konkret punkt vist sit værd som en afhjælpning af mindretallets repræsentationsproblem. Affødt af dette spurgte Peter Gorrsen på mødet i april 1967, »om man ikke i tyske kredse i Sønderjylland var godt tilfreds med kontaktudvalget, idet der vel gennem dette er opnået flere resultater, end Slesvigsk Partis hidtidige repræsentant i folketinget havde kunnet opnå «. Jes Schmidt svarede ifølge det oprindelige referat, "at dette for så vidt var rigtigt, men at det var vanskeligt at udtale dette officielt af hensyn til den tidligere repræsentant for Slesvigsk Parti«. Denne passage ønskede Jes Schmidt efterfølgende rettet, så der kom til at stå: "Jes Schmidt erklærede, at man ikke kunne forvente de tyske medlemmers tilslutning til denne opfattelse, da dette ville være en ret utaknemmelig udtalelse om det arbejde, som Slesvigsk Partis tidligere repræsentant havde ydet i løbet af tre folketingsperioder “. ${ }^{50}$ Man får unægtelig fornemmelsen af, at det første referat gengav Jes Schmidts personlige mening, mens det sidste videregav hans officielle.

\section{Kontaktudvalgets arbejde 1964-1973: Andre spørgsmål}

En tredje knast, som beskæftigede kontaktudvalget igennem adskillige møder, var tilskuddet til mindretallets biblioteksvasen. Biblioteksloven gav kun staten mulighed for at yde støtte til ét bibliotek inden for en kommune, og det ramte - formentlig ganske utilsigtet - min- 


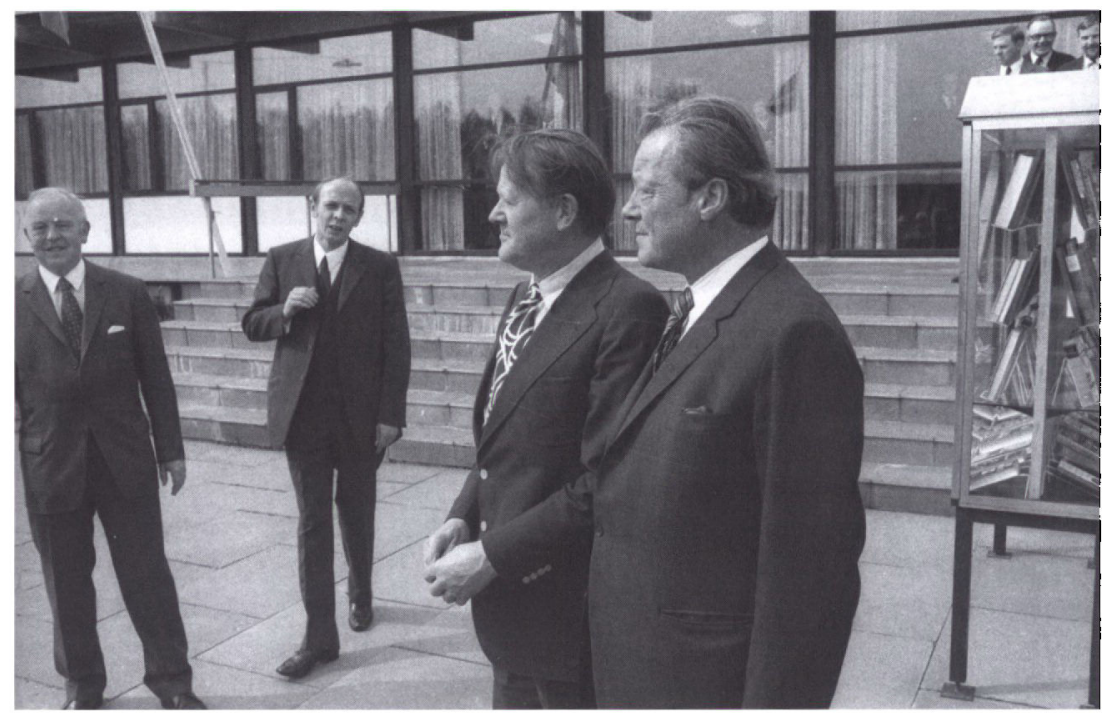

Tilskuddet til det tyske bibliotekswæsen var fra de første moder $i$ kontaktudvalget og mange àr frem et ulost spergsmall $i$ forholdet mellem mindretal og stat. Forst i 1989 fandt man en varig losning. Her ses $i$ forgrunden statsminister Jens Otto Krag og forbundskansler Willy Brandt foran det tyske centralbibliotek $i$ Vestergade $i$ Aabenraa i maj 1972. Sven Geerthsen foto i Museum Senderjylland - ISL.

dretallet, der på mødet i september 1965 ønskede bestemmelsen ændret og desuden centralbiblioteksstatus for sit hovedbibliotek i Aabenraa. Kulturministeren lovede at forelægge problemet for biblioteksrådet, der imidlertid konkluderede, at loven ikke gav mulighed for nogen af delene. Eneste tilbageværende mulighed var derfor en særbevilling på finansloven, og det fandt regeringen dengang ikke mulighed for under statsfinansernes trængte situation. Fra og med finansåret 1968/69 blev der imidlertid bevilget et statstilskud på $30.000 \mathrm{kr}$. til det tyske centralbibliotek i Aabenraa, ligesom det nye Sønderjyllands Amt fra ca. 1973 bevilgede $45.000 \mathrm{kr}$. En grundlæggende løsning blev imidlertid ikke opnået i den periode, som her undersøges. ${ }^{51}$ Det skete først i 1986, hvor statens tilskud blev stærkt forøget, så det nåede op på at finansiere en tredjedel af det tyske biblioteksvæsen i Nordslesvig. Sønderjyllands Amt ogede sit tilskud, og en aftale mellem amtet og kommunerne fra 1989 sikrede, at de fleste sønderjyske kommuner også bidrog. ${ }^{52}$

Også andre af kontaktudvalgets sager drejede sig om rammerne, herunder ikke mindst de økonomiske, for det tyske mindretals institu- 
tioner. I september 1965 beklagede mindretallet sig over kommunernes holdning til oprettelse af tyske børnehaver. Der fandtes på dette tidspunkt 20 tyske børnehaver i landsdelen, og 13 af dem var anerkendt som berettiget til offentlige tilskud. Nogle steder nægtede kommunerne imidlertid at give en sådan anerkendelse. Mindretallet ønskede således at oprette en børnehave for Gråsten og omegn. Gråsten Kommune ville nok yde tilskud hertil, men kun til børn fra kommunen selv, og omegnskommunerne ville slet ikke yde tilskud. I Rinkenæs afviste man at yde tilskud til en ny tysk børnehave, fordi der var ledige pladser i de eksisterende børnehaver. Mindretallet anmodede socialministeren om, at der udsendtes et cirkulære til kommunerne, der pålagde dem at tage hensyn til dets særlige forhold, jf. $\$ 68$ i børne- og ungdomsforsorgsloven, som muliggjorde en sådan særlig hensyntagen. Ministeren og de danske udvalgsmedlemmer var imidlertid ikke indstillet på at indskrænke kommunernes frie skøn, men ministeren lovede, »at hvis man kunne se, at der var en god begrundelse for at »dreje « bestemmelsen for det tyske mindretal, da ville man gøre det, men han måtte afstå fra at lade tilsagnet komme til udtryk $\mathrm{i}$ et cirkulære - det var et tilsagn givet over bordet «. Det måtte mindretallet så nøjes med. ${ }^{53}$

Et beslægtet problem udgjorde befordringstilskuddet til tyske skoleelever. Nogle kommuner afslog dette med henvisning til, at de havde egne realskoler med ledige pladser. Her blev der i forbindelse med friskolelovgivningen givet kommunerne mulighed for at yde et tilskud på 85 $\%$ af befordringsudgiften, dog ikke mere end gennemsnittet for befordringstilskuddet til kommunens egne skoler. Ordningen var frivillig, men staten henstillede til kommunerne at yde dette tilskud. ${ }^{54}$

En løsning opnåedes også, da de statslige byggekvoter for børnehaver, biblioteker og skoler 1965/66 skabte problemer bl.a. for planerne om opførelsen af en tysk sportshal $i$ Tinglev. De blev løst ved at kombinere Undervisningsministeriets og Boligministeriets byggekvoter, så byggeomkostningerne på en million kr. kunne dækkes og byggeriet sættes i værk..$^{55}$ Derimod opnåedes i den her behandlede periode intet resultat m.h.t. statstilskud til tysk teater $i$ grænselandet. ${ }^{56}$

Mindretallets repræsentanter klagede ved flere lejligheder over, at danske myndigheder fravalgte annoncering $i$ "Der Nordschleswiger «. Det gjaldt forsvaret og DSB. Klagerne havde deres baggrund i København-Erklæringen fra 1955, som forpligtede myndighederne til at tage et rimeligt hensyn til mindretallets avis ved bekendtgørelser. ${ }^{57}$ Retningslinjerne blev af kontaktudvalget præciseret således, at almen in- 
formation til borgerne skulle annonceres $i$ alle blade, mens hvervekampagner for FN-tjeneste og reklame for DSB's forskellige billetordninger måtte ske $i$ et udsnit af aviser, som blev udvalgt ud fra markedsføringsmæssige overvejelser. ${ }^{58}$

Sager om diskrimination af enkelte mindretalsmedlemmer var sjældent på kontaktudvalgets dagsorden. Den nationale afspænding var efterhånden nået så vidt, at sådant var blevet rene undtagelsestilfælde. To eksempler fandtes dog. Ved ansøgning om dansk indfødsret havde "en underordnet instans" over for ansøgeren givet udtryk for, at det svækkede hans sag, at han havde sat sine børn i tysk skole. Og en skoleinspektør havde påtalt over for en af sine lærere, at denne havde sine børn i tysk børnehave. I begge tilfælde tog udvalgets danske repræsentanter afstand fra det skete, og man ville have navnene på de formastelige frem. Indenrigsministeren mente imidlertid, at der måtte skelnes mellem de to tilfælde: "Et er, hvad myndighederne i en indfødsretssag foretager sig, noget ganske andet er, hvad privatpersoner måtte blive udsat for $i$ det daglige liv. Med hensyn til det sidste bemærkede han, at såfremt en person måtte mene, at han har været udsat for en utilbørlig pression fra sin nærmeste overordnede, da måtte han indgive klage over den pågældende til hans foresatte, eventuelt til undervisningsministeren. Det er aldeles oprørende, at den slags kan finde sted, men det er ikke et spørgsmål, som kontaktudvalget kan tage sig af «.59 Derimod kunne justitsministeren svare klart negativt på Jes Schmidts spørgsmål i 1968 om, hvorvidt der stadig førtes kartoteker over medlemmerne af det tyske mindretal. Spørgsmålet var foranlediget af tidens debat om efterretningstjenestens registrering af politisk virksomhed. ${ }^{60}$

Flere af de store og små sager, som mindretallet tog op i udvalget, havde rod i dansk-tyske grænseproblemer. De skyldtes asymmetriske regelsæt på dansk og tysk side med hensyn til beskatning, indregistreringsafgift på biler, pensioner og renteydelser, krigsinvalideydelse, autorisation af sygeplejersker, gebyrer på rejsepas, kommunal valgret m.v. Problemerne ramte ikke mindst de vesttyske funktionærer, som arbejdede $\mathrm{i}$ kortere eller længere tid i mindretallets tjeneste, først og fremmest i dets skolevæsen. Da de ikke direkte havde relation til mindretallet som sådant og typisk var af udpræget lovteknisk karakter, skal de ikke refereres nærmere her. ${ }^{61}$ En yderligere bilateral aftale mellem Danmark og Forbundsrepublikken var en kulturaftale, som var under forberedelse i 1972. Den skulle være en traditionel kulturaf- 


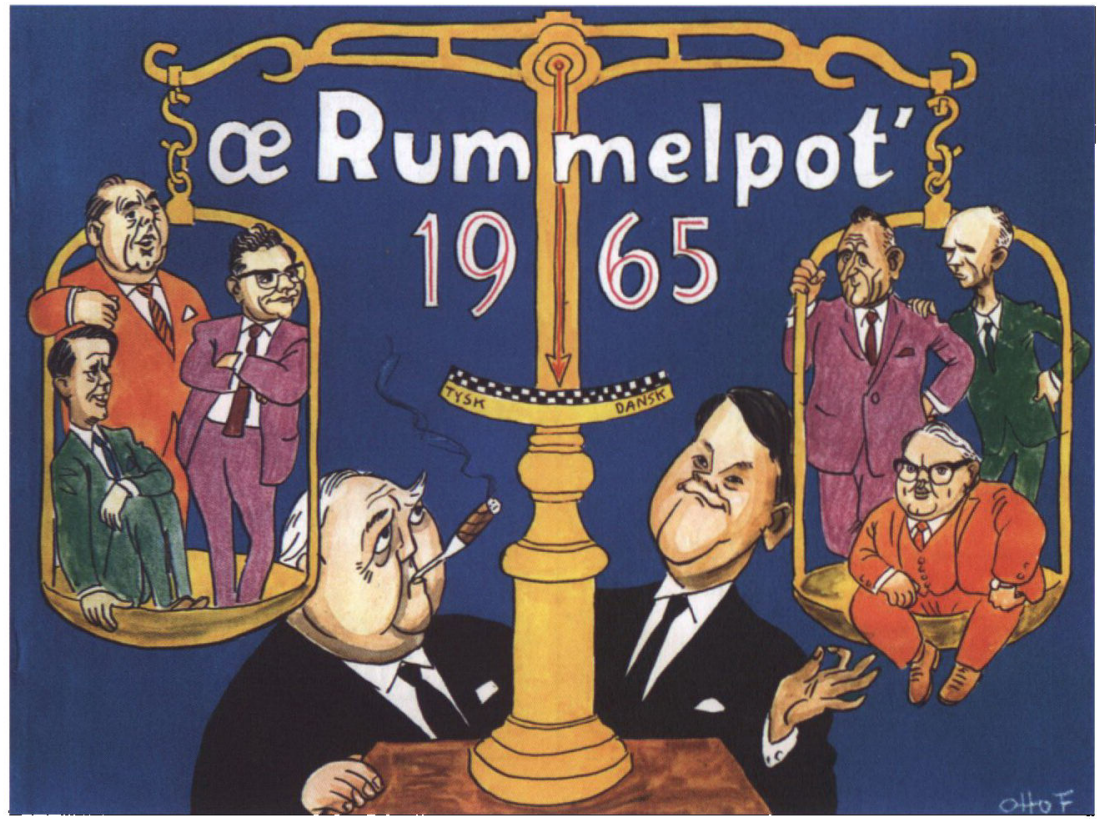

At Danmark og Tyskland tilstræbte en ligelig behandling af de to slesvigske mindretal, forstod også tegneren Otto Frederiksen. P\& forsiden af "ख Rummelpot " 1965 så man forbundskansler Ludwig Erhard og statsminister Jens Otto Krag noje kontrollere, at de to nyoprettede kontaktudvalg opvejede hinanden. Til venstre ses de danske sydslesvigeres repræsentanter $i$ kontaktudvalget $i$ Bonn, bestående af redaktør Karl Otto Meyer fra Flensborg, landdagsmand Berthold Bahnsen fra Lxk og skoleleder Ernst Meyer fra Medelby. Til højre de tyske nordslesvigeres repræsentanter $i$ kontaktudvalget $i$ København, gårdejer Harro Marquardsen fra Faorby, redaktor Jes Schmidt fra Aabenraa og skolekonsulent Arthur Lessow fra Aabenraa.

tale, og mindretalsforhold var i overensstemmelse med den almindelige danske holdning udtrykkeligt holdt udenfor. Mindretallets ledere ønskede ikke desto mindre at få aftalen til udtalelse, før den blev indgået. Kulturministeren gav tilsagn om at forelægge den for begge mindretal, såfremt Udenrigsministeriet ikke havde indvendinger herimod. Det skete da også i det følgende møde. ${ }^{62}$

\section{Kontaktudvalgets arbejde 1964-1973: En vurdering}

Udadtil gav mindretallet $\mathrm{i}$ hvert fald $\mathrm{i}$ begyndelsen udtryk for betydelig tilfredshed med kontaktudvalgets arbejde. ${ }^{63}$ Den omfattede dog ikke den tidligere folketingsmand Hans Schmidt. Han opponerede 
imod, at kontaktudvalget blev omtalt som et "Modellfall« og mente i stedet, at det tjente som en "fremskynder af det tyske mindretals undergang «, uden at det helt stod klart, hvordan det skete. ${ }^{64} \mathrm{Da}$ kontaktudvalget havde fungeret i nogle år og holdt en del møder, gjorde en vis skuffelse sig gældende hos BdN's ledelse. I forbindelse med spørgsmålet om tilskud til mindretallets teatervirksomhed fremkom Harro Marquardsen i november 1972 således med et frustreret udbrud: "Det var nu det 13. kontaktudvalgsmøde mindretallets repræsentanter deltog $i$, og han forespurgte indtrængende, om udvalget dog ikke en gang imellem kunne imødekomme mindretallets ønsker. Kan der ikke ydes et tilskud, inden teaterloven måtte træde i kraft? «. ${ }^{65}$ Ser man bort fra pensionssagen, som netop blev løst $i$ begyndelsen, må det også erkendes, at mindretallet ikke opnåede alverden, når det gjaldt de konkrete onsker. Hvor en løsning måtte afvente en lovændring som i biblioteks- og teatertilskudssagerne, trak den let $\mathrm{i}$ langdrag. I bedste fald opnåedes foreløbige lappeløsninger ad administrativ vej, som det skete i bibliotekssagen. Generelt gik det bedre, når sagerne kunne afgøres på det administrative plan som i spørgsmålet om den tyske hal i Tinglev.

En bedømmelse af udvalgets arbejde må imidlertid også inddrage de frembragte sagers karakter. Så godt som ingen af dem handlede om diskrimination endsige forfølgelse af mindretalsmedlemmer. For så vidt afspejlede sagerne, at den nationale afspænding ti år efter København-Bonn-Erklæringerne var nået langt. Adskillige sager skyldtes, at mindretallet befandt sig i en klemme i dansk lovgivning eller mellem dansk og tysk lovgivning. I disse tilfælde var det ganske utilsigtet og ikke udtryk for nogen diskrimination af mindretallet, men for, at lovgivning i det moderne samfund er kompliceret og ikke altid får taget højde for alle aspekter.

Kontaktudvalget kunne ikke skaffe en bedre løsning på mindretallets repræsentationsproblem end den, som udvalget i sig selv udgjorde. En fritagelse af mindretallet for $2 \%$ spærregrænsen havde næppe haft den ønskede virkning på længere sigt, men havde rummet en betydelig signalværdi og ville for alvor have stillet Danmark i et godt mindretalspolitisk lys. De danske partier var imidlertid ikke indstillet på at foretage den fornødne ændring i valgloven.

Mindretallet bragte ikke det oprindelige ønske om en af mindretallet udpeget sekretær frem i udvalget, skønt besættelsestiden gled stadig længere tilbage i hukommelsen. Mindretallet viste tværtimod 
"fingerspitzengefühl« ved ikke at udpege Rudolf Stehr, der i danske øjne havde en belastet fortid, men ellers som generalsekretær havde været et naturligt valg. ${ }^{66}$

På dansk side udpegede partierne ofte sønderjyske folketingsmedlemmer som Peter Gorrsen (A), Simon From og Johan Philipsen (V), Poul Schlüter og Johs. Burgdorf (C) og Jens Peter Jensen, Agerskov (R). Udvalgets formand var ifølge den oprindelige forretningsorden statsministeren, og Jens Otto Krag indtog da også formandsstolen i de første år 1965/66, men derefter gik han over til at lade næstformanden, indenrigsminister Hans Hækkerup, tage sig af møderne. Hilmar Baunsgaard mødte tilsvarende kun en enkelt gang, nemlig ved det første møde efter at han havde overtaget statsroret, derefter tog indenrigsministrene Poul Sørensen og H.C. Toft over. I $1971 \mathrm{blev}$ konsekvensen heraf taget. På mødet den 28. april 1971 meddelte indenrigsministeren, at udvalget var overført fra Stats- til Indenrigsministeriet. Dermed blev indenrigsministeren formand, mens undervisningsministeren $\mathbf{i}$ henhold til den nye forretningsorden blev næstformand. Det vakte naturligt nok nogen forundring i mindretallet, at denne ændring skete uden nogen forudgående drøftelse i udvalget, selv om man ikke havde noget imod forandringen som sådan.

Samtidig blev det mindste antal møder nedsat fra to til et årligt. Også det knæsatte en allerede igangværende udvikling: Fra fire møder i 1965 indskrænkedes antallet til to møder i 1966 og derefter til ét årligt møde med undtagelse af 1972, hvor der holdtes to. Denne reduktion afspejlede vel, at det var vanskeligt at finde nemme løsninger på de problemer, som mindretallet bragte frem - men også, at mindretallets problemer ikke var af så alvorlig karakter, at mindretallet benyttede sig af $\sin$ mulighed for at kræve flere møder afholdt.

\section{Udblik}

Ved valget af Jes Schmidt på Centrumdemokraternes liste til Folketinget i december 1973 mistede kontaktudvalget noget af sin betydning, men det fortsatte - dog uden repræsentant for Socialistisk Folkeparti, som fandt, at forudsætningen for udvalgets nedsættelse var bortfaldet med valget af Schmidt. ${ }^{67}$ Denne nye fase af kontaktudvalgets udvikling skal dog ikke behandles her, lige så lidt som udvalgets videre historie frem til nutiden.

Derimod skal det nævnes, at det danske mindretal i Sydslesvig i 
juni 1965 fik et kontaktudvalg i Bonn. Forbundsindenrigsminister Hermann Höcherl kaldte $\mathbf{i}$ den forbindelse den danske regerings ordning med det tyske mindretal forbilledlig og et forbillede for den ordning, de danske sydslesvigere nu fik. ${ }^{68}$ Den uofficielle gensidighedstankegang virkede nok engang. ${ }^{69}$ Med dannelsen af udvalget i Bonn var der etableret kontaktudvalg på begge sider af den dansk-tyske grænse, og denne form for erstatning for en repræsentation i parlamentet kom dermed til at indgå i det, man har kaldt »den slesvigske model « for løsning af nationale mindretalsproblemer. ${ }^{70}$

Etableringen af kontaktudvalget med det tyske mindretal blev ikke sidste gang, den danske regering måtte søge en løsning på det tyske mindretals problemer med den politiske repræsentation. Da samarbejdet mellem Slesvigsk Parti og Centrumdemokraterne gik i stykker i 1979, fordi mindretallet stillede med en kandidat med en SS-fortid, som CD ikke kunne acceptere, søgte man efter en ny løsning, der kunne supplere kontaktudvalget. I 1983 blev der således etableret et sekretariat for det tyske mindretal i København. Nu var den tid forbi, hvor dette kunne fremkalde mindelser om besættelsestiden. Der blev dog ikke tale om, at sekretariatet blev sat til at lede kontaktudvalgets arbejde. Ikke mindst takket være valget af redaktør Siegfried Matlok til leder af sekretariatet opnåede mindretallet at få gjort folketingsmedlemmer, embedsmænd i centraladministrationen og medier bevidste om mindretallets problemer i en grad, som ellers næppe havde været opnåelig. ${ }^{71}$

Foreløbig sidste gang, regeringen forestod en ændring af mindretallets forhold, var ved tilvejebringelsen af særlige ordninger for mindretallets repræsentation efter den danske kommunalreform ("strukturreform «), der trådte i kraft ved årsskiftet 2006/07. Det besluttedes, at byrådene $\mathrm{i}$ de fire nye kommuner Haderslev, Aabenraa, Sønderborg og Tønder alle skal bestå af det maksimalt tilladte antal medlemmer, nemlig 31, så Slesvigsk Parti får de bedste chancer for at få valgt et byrådsmedlem ad ordinær vej. Mislykkes dette, kan SP få tildelt et mandat uden stemmeret, såfremt partiet opnår mindst $25 \%$ af det stemmetal, det billigste mandat kræver. Dette skete ved valget i 2005 i Haderslev Kommune, mens SP i 2009 her opnåede et fuldgyldigt mandat. Opnår SP mellem $10 \mathrm{og} 25 \%$ af stemmerne, som kræves til det billigste mandat, skal der oprettes et kommunalt kontaktudvalg med borgmesteren som formand. SP's muligheder for selvstændig repræsentation bortfalder ikke, selv om SP indgår i valgforbund med 
andre partier. Derudover får Slesvigsk Parti en plads i det regionale vækstforum for Syddanmark. Med denne ordning af den politiske repræsentation på kommunalt niveau har mindretallet opnået en "positiv særbehandling «. ${ }^{72}$

Mandater uden stemmeret er således indført som et mellemstadium mellem den ordinære repræsentation og kontaktudvalgsmodellen.

\section{KILDER OG LITTERATUR}

\section{Utrykte kilder}

Rigsarkivet, Udenrigsministeriets arkiv, gruppeordnede sager 1945-72 (RA, UM):

7.X.5.c. Det tyske mindretals repræsentation i Danmarks Rigsdag

7.X.5.d. Kontaktudvalget for det tyske mindretal

Landsarkivet for Sonderjylland, biblioteket: Det tyske mindretal i Nordslesvig gennem 10 år - 1945/55. Duplikeret rapport.

Archiv der Deutschen Volksgruppe Nordschleswigs (ADVN):

V.III.BDN nr. 255. Vertretung in Kopenhagen. Bildung des Kontaktausschusses 1964-71

V.III.BDN nr. 270. Kopenhagener Kontaktausschuss. Korrespondenz 196671

V.III.BDN nr. 271. Kopenhagener Kontaktausschuss. Protokolle 1965-74

\section{Litteratur}

Becker-Christensen, Henrik m.fl:: Sønderjyllands Amt 1970-1995, Aabenraa 1995.

Fink, Troels: Forhandlingerne mellem Danmark og Tyskland i 1955 om de slesvigske mindretal, Kbh. 1959/2001.

Grænsevagten 1964-65.
Hansen, Ernst Siegfried: Diesteln am Wege, Bielefeld 1957.

Henningsen, Lars N. m.fl.: SSW. Dansksindet politik $i$ Sydslesvig 19451998, Flensborg 1998

Jessen, Franz von: Haandbog $i$ det slesvigske Sporgsmaals Historie, III, Kbh. 1938.

Kühl, Jørgen: Den dansk-tyske mindretalsmodel og Europa, Aabenraa 2003.

Kühl, Jørgen (red.): Kobenhavn-Bonn Erklaringerne 1955-2005, Aabenraa 2005.

List-Petersen, Nis Edwin (red.): Mehr als Bücher - 60 Jahre Bibliotheksarbeit in Nordschleswig, Aabenraa 2009.

Loxtermann, Thomas: Das deutsch-dänische Grenzgebiet als Modell nationalstaatlicher Minderheitenpolitik? Die Minderheitenfrage in Schleswig von den Bonn-Kopenhagener Erklärung von 1955 bis zum Beitritt Dänemarks zur EWG 1973, Münster 2004.

Lubowitz, Frank: "Die Gebiets- und Funktionalreform in Dänemark und die Auswirkungen auf die deutsche Volksgruppe in Dänemark« i Sabine Mecking und Janbernd Oebbecke (red.): Zwischen Effizienz und Legitimität, Paderborn 2009, s. 305-314.

Noack, Johan Peter: Det tyske mindretal under besættelsen, Kbh. 1974.

Statistisk Arbog 1948, 1953, 1957, 1960 , 1965. 
NOTER

1. Se herom min redegørelse hos Hans Schultz Hansen og Henrik Skov Kristensen: »Mindretal og flertal i Nordslesvig 1945-1955« i Kühl (red.): København-Bonn Erklæringerne, s. 169-182.

2. Se herom Jørgen Witte: »København-Bonn Erklæringerne: den statspolitiske baggrund «, sst. s. 219268 samt Fink.

3. Fyldigste behandling på grundlag af trykte kilder har hidtil været Jørgen Kühl: "En selvopfyldende profeti? Kobenhavn-Bonn-Erklæringernes virkningshistorie 1955-2005«, i samme (red.): Kobenhaun-Bonn Erklæringerne, s. 522-530.

4. Om Udenrigsministeriets rolle for mindretalspolitikken, se Loxtermann s. 66-69.

5. Jessen, s. 207-251.

6. Noack, s. $145-150$.

7. Hansen, s. 259-267, 322-325.

8. Valgresultater i Statistisk Arbog 1948, s. 197,1950 , s. 237 og 1953, s. 235.

9. Det tyske mindretal i Nordslesvig gennem 10 år - 1945/55, s. II-0-42.

10. Valgresultater i Statistisk $\AA$ rbog 1953, s. 239,1957 , s. 248 og 1960, s. 281.

11. Se herom bl.a. Grænsevagten 1964, s. 231-234.

12. RA, UM 7.X.5.c.

13. Beregning på grundlag af Statistisk Arbog 1965, s. 238.

14. Se om dette udvalg Henningsen m.fl., s. 219-221.

15. RA, UM 7.X.5.c. Se om dette princip også Loxtermann, s. 81-84.

16. RA, UM 7.X.5.c. Jf. Henningsen m.fl., s. 184-186.

17. RA, UM 7.X.5.d., indenrigsministerens redegørelse på første møde $i$ kontaktudvalget 19.5.1965. Jf. Grænsevagten 1964, s. 275-280.

18. RA, UM 7.X.5.c.

19. Cit. efter Grænsevagten 1964, s. 307.

20. Grænsevagten 1964, s. $310 \mathrm{f}$.

21. Grænsevagten 1964, s. 292-294.

22. Berlingske Tidende 15.10 .1964 , cit. i Grænsevagten 1964, s. 310-312.

23. Grænsevagten 1965, s. $218 \mathrm{f}$.

24. Akter herom i RA, UM 7.X.5.c.

25. Om traditionel dansk uvilje mod traktater og garantier i mindretalsspørgsmål, se Loxtermann, s. 71-81.

26. RA, UM 7.X.5.c..

27. Sst., referat med bilagt forhandlingsskitse.

28. Sst., notat af 2.11.1964.

29. Derimod havde det kontaktudvalg (»Verständigungsausschuss «), som var oprettet i henhold til Kiel-erklæringen af 1949 og som bestod indtil 1958, en dansksindet sekretær, nemlig SSW's landssekretær W.L. Christiansen, jf. Henningsen m.fl., s. 112, 218. Der blev dog ikke opbygget et fast bemandet sekretariat i tilknytning til dette udvalg, og dette fortilfælde var derfor ikke rigtig brugbart for det tyske mindretal.

30. Sst., udateret notat.

31. Se om traditionen for tværpolitisk enighed i mindretalsspørgsmål Loxtermann, s. 62-66.

32. Se herom Loxtermann, s. 135.

33. Sst., Oldenburgs notits af 23.11 . 1964.

34. Resolution 13.1.1965 sst. Stemmetal fra ADVN, V.III.BDN nr. 255, Jes Schmidts oplysning på møde i Grenzpolitischer Rats bestyrelse 23 . 1.1965 .

35. ADVN, V.III.BDN nr. 255 , ref. af møde 23.1.1965.

36. RA, UM 7.X.5.c., P.J.-oversigt nr. 3/ 1965 samt statsministerens brev til ministerkollegerne 3.2.1965. Et officielt referat ses ikke.

37. Sst., resolution og brev til statsministeren fra BdN 9.3.1965.

38. Det blev således aldrig håndhævet, selv om mindretallet ikke fik de ønskede indrommelser med hensyn til spærregrænsen.

39. ADVN, V.III.BDN nr. 255 , ref. af møde 12.4.1965 i Grenzpolitischer Rat.

40. RA, UM 7.x.5.d., ref. af møde 19.5. 1965.

41. ADVN, V.III.BDN nr. 255, ref. af møde 12.4.1965 i Grenzpolitischer Rat.

42. RA, UM 7.x.5.d., ref. af møde 19.5 . 1965. 
43. Sst., beretning om kontaktudvalgets virksomhed for året 1965/66.

44. Sst. ref. af møde 25.5.1966.

45. Om regionrådsformand Carl Holsts og statsminister Lars Løkke Rasmussens intervention over for den slesvig-holstenske ministerprasident i denne anledning, se Sydslesvigsk Årbog 2010, bl.a. Kühl s. 42-47.

46. Sst., ref. af møde 28.4.1971.

47. Sst., ref. af møde 8.3.1972.

48. Sst., beretning for 1968/69 og 1969/ 70. Endvidere ADVN, V.III.BDN nr. 271, ref. af møde 15.10.1969. Becker-Christensen m.fl., s. 107.

49. RA, UM 7.x.5.d., ref. af møder 19.5 . $1965,18.6 .1965,17.9 .1965,25.11$. $1965,9.2 .1966$ og 25.5.1966 samt beretning om kontaktudvalgets virksomhed for året 1965/66.

50. Sst., ref. af møde 24.4.1967 med rettelsesblad.

51. Sst., ref. af møder 17.9. 1965, 9.2. $1966,25.5 .1966,12.4 .1967,5.12 .1968$, 26.11.1970, 28.4.1971, 8.3.1972, 22.11. 1972. ADVN, V.III.BDN nr. 271, ref. af møder $15.10 .1969 \mathrm{og}$ 13.6.1973.

52. Nis Edwin List-Petersen, s. 18f.

53. RA, UM 7.x.5.d., ref. af møde 17.9 . 1965.

54. Sst., ref. af møder $5.12 .1968,26.11$. 1970 og 28.4.1971 samt beretning for $1968 / 69$ og 1969/70. ADVN, V.III. BDN nr. 271, ref. af mede 15.10.1969.

55. RA, UM 7.x.5.d., ref. af møder 17.9.1965, 1.12.1965 og 9.2.1966.

56. Sst., ref. af moder 8.3.1972 og 22.11. 1972. ADVN, V.III.BDN nr. 271, ref. af møde 13.6.1973.

57. Kühl (red.): Kobenthavn-Bonn Erklxringerne, s. 660.

58. RA, UM 7.x.5.d, ref. af møder 25.5.
$1966,12.4 .1967,8.3 .1972$ og 22.11. 1972.

59. Sst., ref. af møde 12.4.1967.

60. Sst., ref. af møde $5.12 .1968 \mathrm{og}$ beretning for 1968/69 og 1969/70. Endvidere ADVN, V.III.BDN nr. 271, ref. af mode 15.10.1969.

61. RA, UM 7.x.5.d., f.eks. ref. af moder 9.2.1966, 25.5.1966, 12.4.1967, 5.12. 1968, 26.11.1970, 28.4.1971, 8.3.1972, 22.11.1972. Endvidere ADVN, V.III. BDN nr. 271, ref. af møder 15.10.1969 og 13.6.1973.

62. RA, UM 7.x.5.d., ref. af møde 22.11.1972. ADVN, V.III.BDN nr. 271, ref. af møde 13.6.1973.

63. Der Nordschleswiger 10 . og 12.2.1966, Kühl (red.): KøbenhavnBonn Erklaringerne, s. 529.

64. ADVN, V.III.BDN nr. 270 , brev fra Schmidt til kontaktudvalgets medlemmer 30.9.1966.

65. RA, UM 7.x.5.d., ref. af made 22.11 . 1972.

66. Sst., beretninger om udvalgets arbejde.

67. Kühl (red.): Kabenhavm-Bonn Erklaringerne, s. 530 . ADVN, V.III.BDN nr. 271, beretning om kontaktudvalgets virksomhed 1974 .

68. Gransevagten 1965, s. 169-172. Kühl (red.): Kobenhavn-Bonn Erklæringerne, s. $511 \mathrm{f}$.

69. Se om gensidighedsprincippet generelt Loxtermann, s. 84-86, 161-164.

70. Se herom Kühl: Den dansk-tyske mindretalsmodel, med omtale af kontaktudvalg s. 194-204.

71. Kühl (red.): Kobenhavn-Bonn Erklæringerne, s. 531f.

72. Sst. s. 533-545 og Lubowitz.

\section{Zusammenfassung}

Bei der Wahl zum Folketing in September 1964 ging der deutschen Minderheit ihr Mandat verloren. Die Minderheit forderte generell eine Abschaffung der $2 \%$ Hürde, die der Kandidat der deutschen Minderheit nicht erreicht hatte. Hier und jetzt wünschte sich die Minderheit ein Gremium, welches dem Staatsministerium unterliegen und dessen Vorsitz der Staatsminister haben sollte. Ein weiterer Mini- 
ster sowie Repräsentanten sämtlicher großer Parteien sollen dem Gremium angehören. Die tägliche Arbeit des Ausschusses solle geleitet werden von einem speziellen Sekretariat, das beim Folketing ansässig sein solle, mit einem von der Minderheit ernannten Leiter. Den letzten Wunsch konnten die dänischen Politiker nicht akzeptieren - zu sehr erinnerte dies an eine Sonderregelung während der deutschen Besatzung. Stattdessen wurde ein Kontaktausschuss ins Leben gerufen, dessen Zusammensetzung den Vorschlägen der Minderheit folgte, jedoch ohne festes Sekretariat und mit einem dänischen Beamten als Sekretär. Die Regelung, die im Mai 1965 in Kraft trat, existiert bis heute. 